\title{
Assessing The African Charter on the Rights and Welfare of The Child (ACRWC) As a Blueprint Towards the Attainment of Children's Rights in Africa
}

\author{
Ramphal Mxolisi Sillah and Tawanda William Chibanda
}

\begin{abstract}
The paper seeks to analyse the provisions of the African Charter on the Rights and Welfare of the Child (ACRWC). The paper seeks to make this analysis based on the harmonisation and monism theories of the relationship between international law and municipal law which states that international pieces of law are essentially created to be domesticated within the municipal law of a state and vice versa. To this end, the ACRWC essentially acts as a blueprint for the facilitation of domestic measures and municipal law aimed at upholding children's rights in Africa. The ACRWC should then be an immaculate blueprint that can be followed by states so as to churn out domestic measures that are in the best interests of the child. The paper however seeks to assess whether there are vague, uncouth and contradictory articles within the provisions of the charter that might be interpreted by the states to the detriment of the rights of the African child.
\end{abstract}

Key Words: Children's rights, African Charter on the Rights and Welfare of the Child, Blueprint, municipal law, international law.

\section{Introduction}

The African Charter on the Rights and Welfare of The Child (ACRWC), entered into force in 1999 under the auspices of the African Union (AU). The ACRWC came into being upon the consideration of the Declaration on the Rights and Welfare of the African Child (AHG/ST.4 Rev.l) adopted by the Assembly of Heads of State and Government of the Organization of African Unity, at its Sixteenth Ordinary Session in Monrovia, Liberia from 17 to 20 July 1979, that recognized the need to take appropriate measures to promote and protect the rights and welfare of the African Child. (African Charter on the Rights and Welfare of the Child, Preamble). The ACRWC also took a leaf from the Charter of the Organization of African Unity recognizes the elevation of Human Rights and the African Charter on Human and People's Rights proclaimed and agreed that everyone is entitled to all the rights and freedoms recognized and guaranteed therein, without distinction of any kind such as race, ethnic group, colour, sex, language, religion, political or any other opinion, national and social origin, fortune, birth or other status. Children are inherently human beings and deserve rights that are enshrined in the African Charter on Human Rights.

The ACRWC was designed to serve as a blueprint for the observance of children's rights by every African country. The African Charter became the epitome of what children's rights ought to be taking into consideration that the child, due to the needs of his physical and mental development requires particular care with regard to health, physical, mental, moral and social development, and requires legal protection in conditions of freedom, dignity and security. (African Charter on the Rights and Welfare of the Child, Preamble). However, the question is whether the ACRWC serves as a perfect blue print towards the upholding of children's rights in Africa. There is need to unearth elements of doubles standards, hypocrisy and blurred articles that might leave room for manipulation by states in the basis of the interpretation of the ACRWC, at the expense of the African child.

\section{The Importance of Upholding Children's Rights}

The importance of upholding children's rights can be summed up using four interrelated reasons. The argument can be divided into the rights argument, social argument, the economic argument and the political argument.

The rights argument states stems from the obligation that is placed on states to fulfil and uphold the rights of children. By virtue of being human beings, children have significant rights that accrue to them. Children also have specific rights that accrue to them on the basis of being children, like the right to play and family. To this end, states have an obligation to put in place measures to fulfil such rights. The failure to put in place such measures will actually be a contravention of international law, as children's rights are enshrined in a plethora of international statues like the United Nations Charter on the Rights of the Child (UNCRC) and the Bill of Rights itself. Although states are not forcefully obliged to adhere to international law, it is 
"diplomatically healthy" to do so. Therefore, upholding children's rights is in fact an international obligation that is necessary for a country's international character as being a civilised state within the international system.

The social argument revolves around the concept of community development. Essentially, children are the roots of all communities. The continuity, survival and integrity of a community depends on children. In Africa, the job of child rearing is seen as being very integral, as the thinking is that the provision for and the protection of children will ultimately lead to the attainment of "positive social benefits" in the future. According to Kaime (2009:39), "children are the trees that perpetuate the forest: without them society will die." What Kaime was simply alluding to is that children are the future and must be taken care of for society to survive in every respect. Positive social benefits like reductions in under 5 mortality rates fall by about half for mothers who have primary school education. (UNICEF, 2006). According to (Vandemoortele and Delamonica, 2000), HIV spreads twice as fast amongst uneducated girls. So it is plain to see that indeed, the upholding of children's rights has a positive social benefit on communities.

The economic argument is based on the notion that investing in children today will have a positive long term impact on economic growth and subsequent economic development. Educating a child today for example will create long term economic competitiveness and the quality and productivity of labour. Early childhood development is very much imperative under the economic argument. A child is most likely to gain significant life building skills during the first five years of life. Skills that will enable the child to undertake important labour tasks in the future. In fact according to (Grantham - McGregor et al., 2007), "the rate of return on investment in early childhood development is higher than investment in "on the job training" during later stages of life." Early childhood development is the first step in the process of human capital development. (Grantham McGregor et al., 2007). If a child does not have access to adequate nutrition during the early years of childhood, the child is most likely to suffer from irreversible and cognitive defects that will render them ineffective workers in the future. (OECD, 2009:16)

Statistics on the economics of education show that if states invest in one extra year of primary education, productivity in the future will increase by 10 - 30 percent (Van der Gaag and Tan; 1998). There is also a gender aspect attached to the economic benefit of upholding children's rights. According to (Gatti and Dollar,1999), providing girls with one extra year of education beyond the average boosts eventual wages by 10 to 20 percent. To this end it can be seen that there is a huge economic benefit if states uphold children's rights.

The political argument is centred on the notion that inadequate social investment will lead to high levels of inequality and deprivation in society and subsequent political upheaval. The very provision of education creates a culture of participation which is integral for the attainment of democracy. The provision of education to girl children reduces the gender disparities in society and this will lead to inclusiveness which is an imperative element of democracy. Today's investment in the wellbeing of children will contribute to the peace and stability of future societies.

\section{The Link Between International Law and Municipal Law}

The link between international law and municipal law can be explained using three basic theories namely, monism, dualism and harmonisation. Of interest for this paper are the monism and harmonisation theories. The monism theory alludes that, all law is essentially part of a universal legal order and regulates the conduct of the individual state. Since all law is part of the same legal order, international law is automatically incorperated into municipal law. (Hot Topics Magazine, 2006,Vol.69.,4) The harmonisation theory states that, if there is a breach of international law, municipal law is applied within the national legal system, leaving the state responsible at the international level for any breach of international law. (Hot Topics Magazine, 2006,Vol.69.,4) Essentially, any piece of international legislation has got an effect on the actual happenings within a state. To this end, the ACRWC should be domesticated at all costs as prescribed by the monism theory. Under the harmonisation theory, states are essentially responsible for the breach of the ACRWC and must put in place measures at the domestic level so as to be able to adhere to the ACRWC. It is therefore imperative that the ACRWC is clear and provides an immaculate blueprint on children's rights that is unambiguous and can be followed by all African for the benefit of the African child.

The discussion has shown that there is a need to uphold children's rights as this has holistic trickle down effects on all sectors of development. It is also imperative that there be an astute guiding international framework for the upholding of children's rights in Africa. States must be guided by clear internationally adorned articles that are implementable and easy to interpret. It is upon this backdrop that there is a need to find out whether the ACRWC has managed to provide such a scenario in Africa.

Analysing the African Charter on the Rights and Welfare of the Child.

The ACRWC is supposed to be an immaculate blueprint for the attainment of children's rights in Africa. As one endeavours to analyse the ACRWC, one must look out for elements of double standards, vague 
articles and elements of hypocrisy. The articles must be easy to interpret and understand such that, states can domesticate the elements enshrined within these articles.

Article 1 is on the obligations of state parties. One has to take note of article 1.1 and 1.2. Article 1.1 reads;

"Member States of the Organization of African Unity Parties to the present Charter shall recognize the rights, freedoms and duties enshrined in this Charter and shall undertake to the necessary steps, in accordance with their Constitutional processes and with the provisions of the present Charter, to adopt such legislative or other measures as may be necessary to give effect to the provisions of this Charter."

Article 1.2 reads

"Nothing in this Charter shall affect any provisions that are more conductive to the realization of the rights and welfare of the child contained in the law of a State Party or in any other international Convention or agreement in force in that State."

Article 1.1 ascribes the idea that states must follow the provisions of the articles enshrined within the charter and make necessary adjustments to their constitutions to suit these provisions. However, article 1.2 goes on to ascribe the idea that if a state's constitution accords children with a higher and more refined constellation of rights, then somehow the provisions of the charter can be overridden by the municipal law of a state. The problem is that these two articles provide a loop hole for sates to ignore the provisions of the "blueprint" under the pretext that their local laws accord children greater rights. The question is who will then assess whether the municipal law of a state has indeed accorded children greater rights than those enshrined in the charter. This simply leaves room for manipulation and ridiculing of the charter, and the subsequent ignoring of the obligation previously imposed on states in article 1.1.

Article 4 is on the best interests of the child. One has to pay attention to article 4.1 and 4.2.

Article 4.1 reads:

In all actions concerning the child undertaken by any person or authority the best interests of the child shall be the primary consideration.

Article 4.2 reads;

In all judicial or administrative proceedings affecting a child who is capable of communicating his/her own views, and opportunity shall be provided for the views of the child to be heard either directly or through an impartial representative as a party to the proceedings, and those views shall be taken into consideration by the relevant authority in accordance with the provisions of appropriate law.

When looking at article 4.1, one can see that the article is rather vague in that it fails to define what is really meant by "the best interests of the child." States and other parties are free to interpret these "best interests" in any way that they want to. States can potentially implement antics that are actually detrimental to the child's physical, mental, emotional and spiritual development, under the guise of adhering to these "best interests". For example, East African states can actually turn a blind eye to female genital mutilation under the pretext that it is in the "best interests" of the girl child. UNICEF estimates that in sub-Saharan Africa, Egypt and Sudan, three million girls and women are subjected to FGM every year (UNICEF 2005). To this end, one can see that this article can actually lead to the abuse of children in a way.

Article 4.2 seems to discriminate against children who are not capable of communicating. The article only provides for children capable of communicating in judicial or administrative proceedings. However, children from all walks of life, with different physical impairments and of different ages are capable of being abused. The article seems to allude to the fact that such children cannot be catered for by the state, due to their inability to communicate. This seems to be a gross violation

Article 7 is on the freedom of expression and it reads:

Every child who is capable of communicating his or her own views shall be assured the rights to express his opinions freely in all matters and to disseminate his opinions subject to such restrictions as are prescribed by laws.

As in article 4.2, the aspect of discrimination on the basis of the ability to communicate is present within article 7. There is a major contradiction within this article. On one hand, children are given the right to express themselves freely. However, their rights are then ostracised by restrictions imposed by municipal law on the levels of freedom of expression (subject to such restrictions as are prescribed by laws). So in other words children do not have the clear freedom of expression. 
Article 8 is on the freedom of association and it reads:

Every child shall has the right to free association and freedom of peaceful assembly in conformity with the law.

This article is contradictory. On one hand children are given the right to associate freely. On the other hand, the right to association and peaceful assembly is restricted by municipal law. This is not to state that children must be radical and rowdy and not abide by the law; but there is the risk that municipal law can essentially prevent the right to association and peaceful assembly completely. Such a scenario is present in Zimbabwe, where acts like the Public Order and Security Act (POSA) 2002, effectively ostracise the freedom of association to such negligible levels that render the freedoms basically non - existent. So this article can leave room for states to effectively thwart the right to freedom of association.

Article 10 is on the protection of privacy and it reads:

No child shall be subject to arbitrary or unlawful interference with his privacy, family home or correspondence, or to the attacks upon his honour or reputation, provided that parents or legal guardians shall have the right to exercise reasonable supervision over the conduct of their children. The child has the right to the protection of the law against such interference or attacks.

This article is noble in that it gives children the right to privacy on one hand. On the other hand, the article goes on to give parents and guardians the right to invade the privacy of the child and, "exercise reasonable supervision" over the conduct of their children. The question however is on the definition of "reasonable supervision." The extent of this so called "reasonable supervision" is not defined. The article leaves the definition of reasonable supervision open, and this gives parents and guardians the leeway to possibly completely circumvent the right to privacy under the guise of "reasonable supervision."

Article 11 is on the right to education. The article states that children must gain access to education. Of importance to note is article $11.2 \mathrm{a}$, which states that;

The education provided to children shall be aimed at, upholding the preservation and strengthening of positive African morals, traditional values and cultures.

The question however is on the definition of these "positive African morals, traditional values and cultures." This lack of clarity on what consists of, "positive African morals, traditional values and cultures" lends doubt as to what exactly the education is aimed at attaining. Due to the open nature of the phrase, one is free to give their own conceptualisation of the phrase, "positive African morals, traditional values and cultures." For all its worth, female genital mutilation (FGM) can be considered by some constituencies as being a positive African culture. Therefore this article leaves room for the abuse of children.

Article 13 is on the rights of handicapped children and provides for the provision of special measures of protection aimed at meeting the physical and moral needs of such children and the creation of conditions which ensure the dignity, promote self-reliance and active participation of such children in the community. Article 13.2 raises eyebrows though.

Article 13.2 reads;

States Parties to the present Charter shall ensure, subject to available resources, to a disabled child and to those responsible for his care, of assistance for which application is made and which is appropriate to the child's condition and in particular shall ensure that the disabled child has effective access to training, preparation for employment and recreation opportunities in a manner conducive to the child achieving the fullest possible social integration, individual development and his cultural and moral development.

This article unearths a peculiar double standard and contradiction which can be interpreted by states to the detriment of the African child. The article seems to give states the right not to cater for the needs of handicapped children. The phrase "subject to available resources" seems to allude to the assertion that states can only go ahead to cater for the needs of handicapped children when they have the resources to do so. The phrase seems to relegate the importance of catering for handicapped children to an issue of secondary importance. If countries are left with "extra change" in their coffers, then they can go ahead and cater for the needs of handicapped children. If a country does not have any "available resources", then the needs of handicapped children cannot be catered for. The major question is on the conceptualisation of these "available resources". In Zimbabwe for 
example, $7 \%$ of the national budget is allocated to defence. (NANGO, Child Budget Analysis and Advocacy, 20098). However, the country is not at war and there is no real immediate threat over the sovereignty and territorial integrity of the country. Therefore, the huge chunk of money being channelled to defence can from one angle be viewed as "available resources" because they are being used for an unworthy cause. On the other hand, an army chief might state otherwise and assert that the budget allocation is being utilised for a worthy cause. To this end, the article becomes difficult to interpret and can actually be interpreted to the detriment of the rights of the handicapped child. This is a worrying development as disability amongst children in Africa is actually rife. Africa has a high percentage of children with disabilities.15 For example, it is estimated that as many as 35 per cent of two to nine year-olds in Djibouti and 31 per cent in Central African Republic live with at least one reported disability. (African Report on Child Well Being in Africa, 2008: 31)

Article 17 is on the rights pertaining to juvenile justice. Essentially all children accused or found guilty of having infringed penal law shall have the right to special treatment in a manner consistent with the child's sense of dignity and worth and which reinforces the child's respect for human rights and fundamental freedoms of others.

Of importance to note is article 17.4 which reads;

"There shall be a minimum age below which children shall be presumed not to have the capacity to infringe the penal law."

Article 17.4 leaves room for the possible abuse of children by the state. The very fact that the "minimum age of criminal responsibility" is not mentioned, gives states the latitude to come up with their own minimum age of criminal responsibility. Such a scenario goes against the doctrine of child protection which is centred on the creation of protected environments, free from elements of possible abuse. Zimbabwe for example is said to have one of the lowest minimum ages of criminal responsibility in the world at 7 years of age. (Zimbabwe National Council for the Welfare of Children, Zimbabwe Children's Charter, 2011: 8). It is assumed that a child of 7 is actually capable of committing a crime wittingly and can therefore be prosecuted for it. It is very debateable whether at such a tender age a child has the ability to commit a crime. From one angle, the thought that a 7 year old has the ability to commit a crime wittingly is actually abusive because at such an age the child's psychological development is largely inclined to play and recreation. Therefore, when the minimum age is set at 7, it creates an environment of risk in that it creates the possibility of prosecution for crimes that will not have been committed wittingly at all.

Article 31 which is probably the most controversial article in the charter is on the responsibilities of the child. According to this article, children have got responsibilities towards their family and society, the State and other legally recognized communities and the international community. Of importance to note under this article are aspects $31, \mathrm{~b}$ and $\mathrm{e}$.

The above mentioned aspects of article 31 read;

The child, subject to his age and ability, and such limitations as may be contained in the present Charter, shall have the duty;

(b) to serve his national community by placing his physical and intellectual abilities at its service;

(e) to preserve and strengthen the independence and the integrity of his country.

This is a very controversial article in many respects as it contradicts with many articles enshrined within the charter. The first contradiction is the very fact that children have been given responsibilities to serve the state and the national community by, "placing their physical and intellectual abilities at its service." This becomes a sort of antithesis of the very essence of the charter itself. The tone and commitment of states to the charter seems to introduce the state as the major custodian of children and their rights. The charter seems to erode the institution of the family as the utmost actor in the provision of children's rights and upholds the state as the apex provider of these rights. However, article $31 \mathrm{~b}$ obligates children to serve the state; the very state that should in actual fact be serving them. The question is who should serve who then? Article $31 \mathrm{~b}$ seems to portray the idea that children have to be grateful to the state for the provision of the rights by undertaking some sort of mandatory "plough back" to the state through the placing of their physical and intellectual abilities at its service.” 
Article 31.e. states that children have an obligation to preserve and strengthen the independence and the integrity of his country. The only way that one can do that is logically through acts of valour and the use of force so as to ward off potential threats to the sovereignty, territorial integrity and independence of the territory. Coupled with article $31 \mathrm{~b}$ which states that children must put their physical abilities at the service of the state, it seems like the article is generally calling for the participation of children in armed conflict on behalf of the state. To this end the article contradicts article 22 which alludes that states must ensure that children are not recruited as soldiers at any cost.

\section{Conclusion}

The ACRWC can be described as a noble innovation as it tries to put in place an international blueprint on children's rights in Africa. The ACRWC essentially provides the basis for the domestication of children's right by states in a bid to ensure that utmost and astute upholding of these rights across the African continent. However, for an international piece of legislation to be effective, it must not leave any loopholes in terms of interpretation by states, as there is a danger that states will twist the provisions of the document so as not to incur the burden of implementation. The paper has presented some of the fault lines of the ACRWC and these include articles $1,47,8,10,11,17$, and 31 . These articles can be manipulated by states in terms o interpretation to the detriment of the rights of the African child.

\section{$\underline{\text { Books }}$}

\section{Bibliography}

[1]. Kaime, T. (2009). The African Charter on the Rights and Welfare of the Child: A socio-legal perspective. Pretoria: University of Pretoria Law Press

\section{Journal Articles}

[2]. Grantham-McGregor, S., Cheung, Y., Cueto, S., Glewwe, P ., Richter, L., Strupp, B. (2007)

[3]. Developmental potential in the fi rst 5 years for children in developing countries, Lancet 2007; 369: 60-70.

[4]. Hot Topics Magazine, 2006,Vol.69.,4

[5]. Vandemoortele, J., and Delamonica, E. (2000). "Education 'Vaccine' against HIV/AIDS." Current Issues in Comparative Education $3(1)$.

\section{Reports}

[6]. African Report on Child Well Being in Africa, 2008

[7]. Dollar, D. and Gatti, R. (1999). Gender inequality, income, and growth: Are good times good for women? Policy Research Report on Gender and Development, Working Paper Series No. 1 May 1999, Development Research Group, The World Bank.

[8]. OECD (2009). Development aid at its highest level ever in 2008. Accessed on the $12^{\text {th }}$ of February 2013 at: http://www.oecd.org/dataoecd/47/52/42458612.pdf.

[9]. UNICEF (2006b). Comparing Child Wellbeing in OECD Countries: Concepts and Methods.

[10]. UNICEF (2005). Early Marriage: A Harmful Traditional Practice: A Statistical Exploration.

\section{Official Documents}

[11]. African Charter on the Rights and Welfare of the Child, 1999

[12]. Zimbabwe National Council for the Welfare of Children, Zimbabwe Children's Charter, 2011

[13]. NANGO, Child Budget Analysis and Advocacy, 2009 